\title{
EFEKTIFITAS LAYANAN BIMBINGAN DAN KONSELING DI SEKOLAH UNTUK MENINGKATKAN KEPERCAYAAN DIRI SISWA
}

\author{
Heru Sriyono \\ Dosen Program Studi Bimbingan dan Konseling Universitas Indraprasta PGRI \\ Email : herusriyono30@gmail.com
}

\begin{abstract}
Abstrak
Penelitian ini bertujuan untuk mengetahui tentang Efektifitas layanan bimbingan dan konseling untuk meningkatkan kepercayaan diri siswa di SMK 28 Oktober Jakarta. Metode penelitian yang digunakan adalah metode kuantitatif dengan pendekatan deskriptif, yaitu dengan cara mengumpulkan data apa adanya dari suatu gejala akan fenomena yang ada ketika penelitian dilakukan. Data dan sumber data dalam penelitian ini adalah guru wali kelas, guru bimbingan dan konseling dan siswa kelas X, dengan teknik penentuan sampel adalah purposive sampling. Instrumen penelitian yang digunakan dalam penelitian ini adalah wawancara observasi dan dokumentasi. Wawancara dilakukan terhadap guru wali kelas guru bimbingan dan konseling serta observasi dilakukan dengan mengamati keadaan lingkungan sekolah dan keberadaan sekolah. Teknik analisa data dilakukan dengan cara mengumpulkan data, mengelompokkan data, menganalisa data dan menginterprestasikan data yang akan disimpulkan menjadi hasil penelitian. Kesimpulan ini adalah peranan guru bimbingan dan konseling lebih efektif dalam memberikan layanan bimbingan dan konseling untuk kelas XA sekolah SMK 28 Oktober Jakarta, dapat dikatakan cukup efektif. Kata Kunci: layanan bimbingan konseling, kepercayaan diri, cukup efektif
\end{abstract}

\section{PENDAHULUAN}

Undang-Undang No. 20 Tahun 2003 tentang sistem Pendidikan Nasional Pasal 111 menjelaskan pendidikan adalah Usaha sadar dan terencana untuk mewujudkan suasana belajar dan proses pembelajaran agar peserta didik secara aktif mengembangkan potensi dirinya untuk memiliki kekuatan spiritual keagamaan, pengendalian diri, kepribadian, kecerdasan, akhlak mulia, serta keterampilan yang diperlukan dirinya dan masyarakat. Pendidikan merupakan kebutuhan sepanjang hayat. Setiap manusia membutuhkan pendidikan sampai kapan dan dimanapun ia berada.

Pendidikan nasional adalah pendidikan yang berdasarkan pancasila dan UndangUndang Dasar Negara Republik Indonesia Tahun 1945 yang berakar pada nilai-nilai agama, kebuayaan nasional Indonesia dan tanggap terhadap tuntutan perubahan zaman. Pendidikan sangat penting artinya tanpa pendidikan manusia sulit berkembang bahkan akan terbelakang. Pendidikan diarahkan untuk menghasilkan manusia yang berkualitas dan mampu bersaing di samping memiliki budi pekerti yang luhur dan moral yang baik.

Proses belajar mengajar merupakan bagian dari pendidikan, yang tidak hanya terbatas pada lembaga formal tetapi juga mencakup lembaga informal baik yang 
berlangsung dalam keluarga, dalam pekerjaan dan dalam kehidupan masyarakat. Dalam konteks pendidikan formal di sekolah, kegiatan belajar mengajar merupakan fungsi pokok dan usaha yang paling strategis guna mewujudkan tujuan institusional yang diemban oleh suatu lembaga.

Hal-hal yang berkaitan dengan proses belajar mengajar, diantaranya: siswa, tujuan, dan guru. Proses belajar mengajar dapat diartikan sebagai suatu rangkaian antara siswa dan guru dalam rangka mencapai tujuannya. Namun dalam kenyataannya, untuk mencapai tujuan proses belajar mengajar yang baik terdapat tantangan atau hambatan yang harus dihadapi. Salah satu hambatan yang terjadi dalam proses belajar mengajar di kelas adalah masalah sosial. Masalah ini timbul sebagai akibat dari siswa yang tidak memiliki kepercayaan diri. Kepercayaan diri merupakan kunci motivasi diri. Individu tidak dapat menjalani hidup dengan baik tanpa kepercayaan diri. Setiap individu akan membutuhkan kepercayaan diri setiap harinya dalam berbagai hal, termasuk siswa dalam mengikuti proses belajar mengajar di sekolah. Tingkat kepercayaan diri yang baik memudahkan pengambilan keputusan dan melancarkan jalan untuk mendapatkan teman, membangun hubungan, dan membantu individu mempertahankan kesuksesan. Individu yang mempunyai kepercayaan diri memiliki perasaan positif terhadap dirinya, punya keyakinan yang kuat atas dirinya dan punya pengetahuan akurat terhadap kemampuan yang dimiliki. Individu yang mempunyai kepercayaan diri bukanlah individu yang hanya merasa mampu tetapi sebetulnya tidak mampu melainkan adalah individu yang mengetahui bahwa dirinya mampu berdasarkan pengalaman dan perhitungannya.

Percaya diri merupakan salah satu aspek kepribadian yang sangat penting dalam kehidupan manusia. Individu yang percaya diri merasa yakin atas kemampuan mereka sendiri serta memiliki pengharapan yang realistis, bahkan ketika harapan mereka tidak terwujud, mereka tetap berpikiran positif dan dapat menerimanya. Selain itu percaya diri mampu menjadi stimulus yang mendorong individu untuk mampu bertindak tanpa ragu. Begitu besar fungsi dan peranan kepercayaan diri pada kehidupan individu. Tanpa adanya rasa percaya diri yang tertanam dengan kuat di dalam jiwa individu, pesimisme dan rasa rendah diri akan dengan mudah menguasai dirinya. Tanpa dibekali kepercayaan diri yang mantap sejak dini, maka individu akan tumbuh menjadi pribadi yang lemah.

Kepercayaan diri pada dasarnya merupakan keyakinan dalam diri seseorang untuk dapat menanggapi segala sesuatu dengan baik sesuai dengan kemampuan diri yang 
dimiliki. Mastuti (2008:13) menyatakan "kepercayaan diri adalah sikap positif seorang individu yang memampukan dirinya untuk mengembangkan penilaian positif baik terhadap diri sendiri maupun terhadap lingkungan/situasi yang dihadapinya”. Wiranegara (2010:3) menyatakan bahwa kepercayaan diri sebenarnya adalah karakter seseorang dengan kepercayaan positif terhadap dirinya sehingga ia bisa mengontrol hidup dan rencana-rencananya. Orang yang percaya diri adalah seseorang yang tahu kemampuan dirinya dan menggunakan kemampuannya untuk berbuat sesuatu. Orang yang percaya diri akan mengambil setiap keuntungan dan kesempatan yang ada di depan matanya.

Rasa percaya diri yang tinggi sebenarnya merujuk pada adanya beberapa aspek dari kehidupan individu tersebut dimana ia merasa memiliki kompetensi, yakin, mampu dan percaya bahwa dia bisa karena didukung oleh pengalaman, potensi aktual, prestasi serta harapan yang realistik terhadap diri sendiri. Kepercayaan diri seseorang sangat dipengaruhi oleh masa perkembangan yang sedang dilaluinya terutama bagi remaja, kepercayaan diri ini akan mudah berubah. Siswa yang duduk di bangku Sekolah Menengah Pertama (SMP) ini tergolong usia remaja awal yang berada pada masa puber yaitu suatu tahap dalam perkembangan dimana terjadi kematangan alat-alat seksual dan tercapai kemampuan reproduksi. Menurut Charlotte Buhler (dalam Hurlock, 1980:185) menamakan "masa puber sebagai fase negative”. Istilah fase menunjukkan periode yang berlangsung singkat; negatif berarti bahwa individu mengambil sikap “anti” terhadap kehidupan atau kelihatannya kehilangan sifat-sifat baik yang sebelumnya sudah berkembang. Remaja yang tadinya sangat yakin pada diri sendiri, sekarang menjadi kurang percaya diri dan takut akan kegagalan. Hal ini terjadi karena daya tahan fisik menurun dan adanya kritik yang datang bertubi-tubi dari orang tua dan teman-temannya.

Individu yang tidak percaya diri memiliki konsep diri negatif, kurang percaya pada kemampuannya, hal ini menyebabkan individu sering menutup diri mereka terhadap dunia luar yang lebih luas. Tanpa kepercayaan diri individu memiliki resiko kegagalan ataupun kurang optimal dalam mengerjakan tugas tugasnya. Berbanding terbalik dengan individu yang memiliki kepercayaan diri tinggi, mereka cenderung berani tampil bahkan tanpa persiapan apapun dan tanpa memikirkan hasilnya. Individu yang kurang memiliki kepercayaan diri menilai bahwa dirinya kurang memiliki kemampuan. Penilaian negatif mengenai kemampuannya tersebut dapat menghambat usaha yang akan dilakukan untuk mencapai tujuan yang akan dicapai. Pandangan dan penilaian negatif tersebut 
menyebabkan individu tidak melakukan sesuatu kegiatan dengan segala kemampuan yang dimiliki. Padahal mungkin sebenarnya kemampuan tersebut dimilikinya.

Tidak semua individu memiliki rasa percaya diri yang cukup. Perasaan minder, malu, sungkan menjadi kendala bagi siswa dalam menjalani proses belajarnya disekolah maupun dilingkunganya. Individu yang selalu beranggapan bahwa dirinya tidak mempunyai kemampuan, merasa dirinya tidak berharga, merupakan gambaran dari orang yang mempunyai masalah kepercayaan diri. Hal ini dapat dimanifestasikan dalam bentuk tingkah laku yang kurang wajar atau menyimpang, misal: rendah diri, terisolir, prestasi belajar rendah.

Berdasarkan data awal yang diperoleh dari hasil wawancara dengan guru bimbingan dan konseling di SMK 28 Oktober Jakarta, diketahui bahwa siswa mengalami masalah kurang percaya diri. Masalah kurang percaya diri yang dialami siswa ini ditunjukkan dengan perasaan grogi saat tampil di depan kelas yang terlihat dari raut wajah dan langkah kaki siswa yang tidak mantap, siswa memiliki rasa malu yang berlebihan ketika menjadi pusat perhatian, siswa memiliki perasaan tidak pantas ketika mendapat pujian, siswa merasa malu menjadi diri sendiri karena merasa dirinya selalu memiliki kekurangan sehingga selalu berusaha untuk menjadi seperti orang lain.

Masalah kurang percaya diri merupakan masalah yang masih serius di SMK 28 Oktober Jakarta. Apabila masalah ini tidak mendapatkan perhatian secara khusus dan mendapatkan penanganan segera dari guru, terutama guru bimbingan dan konseling maka akan menghambat perkembangan siswa dan dikhawatirkan akan mengganggu siswa dalam meraih prestasi yang optimal. Untuk mengatasi masalah ini perlu diupayakan kegiatan yang mengarah pada peningkatan kepercayaan diri siswa.

Informasi lain yang diperoleh, bahwa kurangnya guru bimbingan dan konseling untuk membantu menyelesaikan masalah-masalah yang ada di sekolahan yang ahirnya kurangnya waktu atau kesempatan untuk memberikan layanan di kelas karena tidak adanya jam bimbingan dan konseling. Hal ini merupakan kendala bagi guru bimbingan dan konseling dengan tidak sebandingnya banyaknya jumlah siswa yang ada, maka guru bimbingan dan konseling untuk memberikan layanan tidak optimal dan efektif. Adapun upaya yang sudah dilakukan oleh guru bimbingan dan konseling untuk mengatasi masalah kepercayaan diri dengan memberikan layanan informasi yang diberikan secara klasikal maupun layanan yang lainya seperti Layanan Orentasi, Layanan Informasi, 
Layanan Penempatan dan Penyaluran, Layanan Penguasaan Konten, Layanan Konseling Perorangan, Layanan Konseling Kelompok, Layanan Konsultasi, Layanan Mediasi dan Layanan Advokasi, dalam memberikan layanan informasi. Guru bimbingan dan konseling SMK 28 Oktober Jakarta tidak pernah lupa untuk selalu memberikan nasehat kepada siswa-siswanya diselah-sela waktu yang ada. Namun upaya tersebut masih belum memberikan hasil yang optimal. Berdasarkan informasi tersebut maka, peneliti tertarik untuk memberikan tindakan lebih lanjut guna meningkatkan kepercayaan diri siswa, bimbingan dan konseling yang diberikan sebagai upaya bantuan kepada siswa melalui beberapa layanan yang ada untuk mendapatkan informasi yang berguna agar dapat mengembangkan kemampuan yang dimiliki, menyelesaikan masalah yang dihadapi, mampu menyusun rencana, membuat keputusan yang tepat, serta untuk memperbaiki dan mengembangkan pemahaman terhadap diri sendiri, orang lain,dan lingkungan dalam membentuk perilaku yang lebih efektif. Melalui layanan konseling yang ada siswa dapat mengembangkan sikap dan membentuk perilaku yang lebih baik, mampu mengembangkan keterampilan sosialnya, saling memahami.

Layanan-layanan konseling tepat diberikan kepada siswa SMK 28 Oktober Jakarta. Layanan konseling pada siswa mendorong terjadinya interaksi yang dinamis. Dengan layanan layanan yang diberikan pada siswa diharapkan bisa memberikan bantuan untuk meningkatkan rasa percaya diri pada siswa. Memperhatikan latar belakang di atas, maka peneliti tertarik melakukan penelitian dengan tema Efektifitas Layanan Bimbingan dan Konseling di Sekolah untuk Meningkatkan Kepercayaan Diri Siswa.

\section{TINJAUAN PUSTAKA}

Menurut Frank Parson dalam Prayitno dan Erman Amti, (2004: 93-99) Bimbingan membantu individu untuk memahami dan menggunakan secar luas kesempatankesempatan pendidikan, jabatan, dan pribadi yang mereka miliki atau dapat mereka kembangkan, dan sebagai satu bentuk bantuan penyesuaian yang baik terhadap sekolah dan terhadap kehidupan. Bimbingan adalah bagian dari proses dari pendidikan yang teratur dan sistematik guna membantu pertumbuhan anak muda atas kekuatannya dalam menentukan dan mengarahkan kehidupan sendiri, yang akhirnya dapat memperoleh pengalaman-pengalaman yang dapat memberikan sumbangan yang berarti bagi masyarakat. 
Bimbingan adalah bantuan yang diberikan oleh seseorang, laki-laki atau perempuan, yang memiliki kepribadian yang memadai dan terlatih dengan baik kepada individu-individu setiap usia untuk membantunya mengatur kegiatan hidupnya sendiri, membuat keputusan sendiri dan menangung bebanya sendiri. Bimbingan adalah proses pemberian bantuan yang dilakukan oleh orang yang ahli kepada seorang atau beberapa orang individu, baik anak-anak, remaja, maupun dewasa; agar orang yang dibimbing dapat mengembangkan kemampuan dirinya sendiri dan mandiri; dengan memanfaatkan kekuatan individu dan sarana yang ada dan dapat dikembangkan; berdasarkan normanorma yang berlaku.

Secara etimologis, istilah konseling berasal dari bahasa Latin, yaitu "consilium” yang berarti "dengan" atau "bersama” yang dirangkai dengan "menerima” atau "memahami”. Sedangkan dalam bahasa Anglo-Saxon, istilah konseling berasal dari “sellan” yang berarti “menyerahkan” atau "menyampaikan” seluruh upaya bantuan yang diberikan konselor kepada konseli supaya dia memperoleh konsep diri dan kepercayaan diri sendiri, untuk dimanfaatkan olehnya dalam memperbaiki tingkah lakunya pada masa yang akan datang. Dalam pembentukan konsep kepribadian yang sewajarnya mengenai: dirinya sendiri, orang lain, pendapat orang lain tentang dirinya, tujuan-tujuan yang hendak dicapai, dan kepercayaan diri . (dalam bukunya Prayitno dan Erman Amti, (2004: 99).

Selain itu dalam bukunya Prayitno dan Erman Amti, (2004: 101), mendefinisikan konseling adalah bantuan yang diberikan oleh konselor kepada klien dalam rangka pengentasan masalah klien. Dalam suasana tatap muka yang dilaksanakan interaksi langsung antara konselor dengan klien. Pembahasan masalah tersebut bersifat mendalam menyentuh hal-hal penting tentang klien (bahkan sangat penting yang boleh jadi menyangkut rahasia pribadi klien), bersifat meluas meliputi berbagai segi yang menyangkut permasalahan klien, namun juga bersifat spesifik mengarah pengentasan masalah klien. Konseling merupakan suatu upaya bantuan yang dilakukan dengan empat mata atau tatap muka antara konselor dan klien yang berisi usaha yang laras, unik, human (manusiawi), yang dilakukan dalam suasana keahilan dan yang didasari atas normanorma yang berlaku, agar klien memperoleh konsep din dan kepercayaan diri sendiri dalam memperhaiki tingkah lakunya pada saat kini dan mungkin pada masa yang akan 
datang”.

Berdasarkan berbagai pendapat tersebut diatas dapat disimpulkan, pengertian konseling adalah bantuan secara professional yang diberikan oleh konselor kepada klien secara tatap muka empat mata yang dilaksanakan interaksi secara langsung dalam rangka memperoleh pemahaman diri yang lebih baik, kemampuan mengontrol diri, dan mengarahkan din untuk dimanfaatkan olehnya dalam rangka pemecahan masalah dan memperbaiki tingkah lakunya pada masa yang akan datang.

Tujuan bimbingan dan konseling menurut Prayitno dan Erman Amti (2004: 112), sejalan dengan perkembangan konsep bimbingan dan konseling makan tujuan dan bimbingan konseling pun mengalami perubahan dari yang sederhana sampai yang lebih komprehensif. Perkembangan dari waktu ke waktu dapat dilihat pada kutipan di bawah ini:

1. Untuk membantu individu membuat pilihan-pilihan, penyesuaian-penyesuaian dan interpretasi-interpretasi dalam hubungan dengan situasi-situasi tertentu.

2. Untuk memperkuat fungsi-fungsi pendidikan.

3. Untuk membantu orang-orang menjadi insan yang berguna, tidak hanya sekedar mengikuti kegiatan-kegiatan yang berguna saja.

Melihat arti bimbingan tersebut ada tiga hal penting yang perlu dilaksanakan guru pembimbing yaitu membantu siswa untuk dapat mengenal kekuatan dan kelemahan dirinya, membantu siswa agar sanggup mengenal berbagai macam aspek dalam kehidupannya berupa pendidikan, pekerjaan, kebudayaan sehingga siswa mampu merencanakan masa depannya.Semua bantuan ini diberikan melalui konseling. Konseling adalah suatu nama dalam arti luas untuk aneka ragam produser bantuan kepada individuindividu mancapai penyesuaian, seperti pemberian nasihat diskusi yang bersifat terapi kegiatan administrasi dan inter prestasi berbagai tes dan bantuan vokasional.

Dari uraian diatas kita dapat menyimpulkan bimbingan merupakan tujuan, sementara konseling adalah proses kegiatan untuk mencapai tujuan. Secara umum, tujuan dan bantuan pelayanan bimbingan dan konseling adalah membantu siswa mengenal kekuatan dan kelemahan dirinya, serta menerima dirinya secara positif dan dinamis sebagai modal pengembangan diri lebih lanjut. Bimbingan juga membantu siswa dalam rangka mengenal lingkungan secara objektif, baik lingkungan sosial, ekonomi, dan budaya. Maupun norma-norma dan nilai-nilai kehidupan. Pengenalan lingkungan tersebut 
meliputi rumah, sekolah, alam, dan masyarakat sekitarnya. Dengan demikian, siswa diharapkan dapat memanfaatkan lingkungan untuk pengembangan dirinya secara mantap dan berkelanjutan. Selanjutnya bantuan dalam perencanaan masa depan dimaksudkan agar siswa mampu mempertimbangkan dan mengambil keputusan tentang masa depannya sendiri yang menyangkut bidang pendidikan, karir, keluarga, budaya, maupun masyarakat.

Fungsi bimbingan dan konseling menurut Prayitno dan Erman Amti (2004: 196215), fungsi bimbingan dan konseling ditinjau dari kegunaan atau manfaat, ataupun keuntungan-keuntungan apa yang diperoleh melau pelayanan tersebut, fungsi-fungsi bimbingan dan konseling antara lain:

1. Fungsi Pemahaman

Dalam fungsi pemahaman yang utama adalah klien dengan berbagai permasalahannya, dan dengan tujuan-tujuan konseling itu sendiri pemahaman tentang diri klien berserta permasalahannya oleh klien sendiri dan oleh pihak-pihak yang akan membantunya klien, serta pemahaman tentang lingkungan klien oleh klien (pemahaman yang menyangkut latar belakang pribadi klien, kekuatan dan kelemahan, serta kondisi lingkungan).

2. Fungsi Pencegahan

Yaitu, menghindari timbulnya atau meningkatnya kondisi bermasalah pada diri klien, mempunyai dan menurunkan faktor organik dan setres; serta meningkatkan kemampuan pemecahan masalah penilaian positif terdapat diri sendiri, dan dukungan kelompok.

3. Fungsi Pengentasan

Yaitu, mengentaskan masalah yang diderita oleh klien dengan cara paling cepat, cermat, dan tepat. Sehingga masalah yang dialami oleh klien akan terselesaikan dengan tuntas dan tidak kembali lagi.

4. Fungsi Pemeliharaan dan Pengembangan

Yaitu, bantuan yang diberikan konselor pada klien agar ia mampuh mengembangkan diri secara optimal, memelihara segala sesuatu yang baik yang ada pada individu, baik hal itu merupakan pembawaan maupun hasil-hasil perkembangan yang telah dicapai selama ini

Menurut Eka Nastasya (2016:1) salah satu penulis jurnal Bidang Pelayanan dan 
Pengembangan Bimbingan dan Konseling membahas bidang pelayanan pribadi. Dalam bidang bimbingan pribadi, pelayanan bimbingan dan konseling membantu siswa menemukan dan mengembangkan pribadi yang beriman dan bertaqwa terhadap Tuhan Yang Maha Esa, mantap dan mandiri serta sehat jasmani dan rohani.

1. Bidang bimbingan pribadi dapat dirinci sebagai berikut:

a. Penanaman dan pemantapan sikap dan kebiasaan serta pengembangan wawasan dalam beriman dan bertaqwa terhadap Tuhan Yang Maha Esa.

b. Penanaman dan pemantapan pemahaman tentang kekuatan diri dan pengembangannya untuk kegiatan-kegiatan yang kreatif dan produktif, baik dalam kehidupan sehari-hari maupun peranan untuk dimasa depan.

c. Pemantapan kemampuan mengambil keputusan

2. Bidang Pelayanan Sosial

Dalam bidang bimbingan sosial, pelayanan bimbingan dan konseling membantu siswa dalam proses sosialisasi untuk mengenal dan berhubungan dengan lingkungan social yang dilandasi budi pekerti luhur dan rasa tanggung jawab. Pokok-pokok materi dalam bidang bimbingan sosial adalah sebagai berikut:

a. Pengembangan kemampuan berkomunikasi baik melalui ragam lisan maupun tulisan secara efektif.

b. Pengembangan kemampuan bertingkah laku dan berhubungan social, baik di rumah, di sekolah, maupun di masyarakat dengan menjunjung tinggi tata karma, sopan santun serta nilai-nilai agama, adat, peraturan dan kebiasaan yang berlaku.

3. Bidang Pelayanan Belajar

Dalam bidang bimbingan belajar, pelayanan bimbingan dan konseling membantu siswa mengembangkan kebiasaan belajar yang baik dalam menguasai pengetahuan dan keterampilan, serta menyiapkannya untuk melanjutkan pendidikan pada tingkat yang lebih tinggi. Pokok-pokok materi dalam bidang bimbingan belajar adalah sebagai berikut:

a. Pengembangan sikap dan kebiasaan belajar untuk mencari informasi dari berbagai sumber belajar, bersikap terhadapa guru dan nara sumber lainnya, mengikuti pelajaran sehari-hari, mengerjakan tugas (PR), mengembangkan keterampilan belajar, dan menjalani program penilaian.

b. Pengembangan disiplin belajar dan berlatih, baik secara mandiri maupun 
kelompok.

\section{Bidang Pelayanan Karir}

Dalam bidang bimbingan karir, pelayanan bimbingan dan konseling membantu siswa mengenali dan mulai mengarahkan diri untuk masa depan karir. Pokok-pokok materi dalam bidang bimbingan karir adalah sebagai berikut:

a. Pengenalan awal terhadap dunia kerja dan usaha memperoleh penghasilan untuk memenihi kebutuhan hidup.

b. Pengenalan, orientasi dan informasi karir pada umumnya, secara sederhana

Menurut Haryanto (2010:4) percaya diri adalah adalah Figur yang sempurna dan mampuh melakukan apa saja, atau memiliki penampilan fisik tampa cacat sedikitpun. Mungkin di antara mereka ada beberapa orang yang minder karena memiliki kekurangan misalnya hidung pesek, tubuh mungil, rambut kribo, dan lai-lain.

Menurut Thantaway dalam kamus Istilah Bimbingan dan Konseling (2005:85) percaya diri adalah Kondisi mental atau piskologis diri seseorang yang memberi keyakinan kuat pada dirinya untuk berbuat atau melakukan sesuatu tindakan. Orang yang tidak percaya diri memiki konsep diri negatif, kurang percaya pada kemampuannya, karna itu sering menutup sendiri. Orang yang percaya diri memiliki sikap atau perasaan yang yakin pada kemampuan sendiri. Keyakinan itu dapat muncul setelah seseorang tahu apayang dibutuhkan dalam hidupnya. Jadi, dalam hidup ini kita tidak perlu lagi membandingkan bandingkan kemampuan kita dengan orang lain dan jangan mudah terpengarui oleh orang lain.

James Neill (2014:51-52) menyebutkan beberapa istilah yang terkait dengan persoalan percaya diri, yaitu:

\section{a. Self-Concept}

Bagaiman Anda menyimpulkan diri anda secara keseluruhan, bagaimana Anda melihat potret diri Anda secara keseluruhan, bagaimana Anda mengkonsepsikan diri anda secara keseluruhan.

\section{b. Self-Esteem}

Sejauh mana Anda punya perasaan positif terhadap diri Anda, sejauhmana Anda punya sesuatu yang Anda rasakan bernilai atau berharga dari diri Anda, sejauh mana Anda meyakini adanya sesuatu yang bernilai, bermartabat atau berharga di dalam diri Anda. 


\section{c. Self Efficacy}

Sejauh mana Anda punya keyakinan atas kapasitas yang Anda miliki untuk bisa menjalankan tugas atau menangani persoalan dengan hasil yang bagus to succeed. Ini yang disebut dengan general self-efficacy. Atau juga, sejauhmana Anda meyakini kapasitas anda di bidang anda dalam menangani urusan tertentu. Ini yang disebut dengan specific self-efficacy.

\section{d. Self-Confidence}

Sejauhmana Anda punya keyakinan terhadap penilaian Anda atas kemampuan Anda dan sejauh mana Anda bisa merasakan adanya "kepantasan” untuk berhasil. Self confidence itu adalah kombinasi dari self esteem dan self-efficacy.

Rasa percaya diri akan menentukan bagaimana seseorang akan menilai dan menghargai dirinya.Tingkat kebijaksanaan juga akan mempengarui apakah sesorang akan punya rasa percaya diri yang tinggi atau rendah.selain itu, kualitas dari rasa percaya diri ini bisa diukur berdasarkan berbagai kritiria, misalnya stabilitas dan konsistensi. Orang yang kurang percaya diri akan terlihat dari sikap dan tindakanya. Misalnya, tidak yakin pada diri sendiri, selalu bergantung pada orang lain, dan tidak berani mengambil keputusan. Meskipun telah dinyatakan bahwa orang yang kurang percaya diri cenderung untuk melakukan kesalahan, namun pernyataan itu tidak selalu benar. Menurut berbagai penelitian terbaru, "terlalu percaya diri” lebih berbahaya disbanding kurang percaya diri, mereka mengeklaim bahwa para para penjahat dan pelaku criminal mungkin punya percaya diri yang sangat tinggi.

\section{METODE}

Penelitian dilakukan di Sekolah SMK 28 Oktober Jakarta, yang berlokasi di Jakarta beralamat di Jalan Mampang Prapatan XI, Pancoran Jakarta Selatan dilaksanakan pada bulan Juni sampai dengan Agustus 2016 (kurang lebih tiga bulan). Penelitian ini menggunakan pendekatan kualitatif. Dengan teknik pengambilan data Observasi, wawancara dan studi dokumen. Nasution dalam Sugiyono (2013: 309-315) menyatakan bahwa, observasi adalah dasar semua ilmu pengetahuan. Para ilmuwan hanya dapat bekerja berdasarkan data yaitu, data itu dikumpulkan dan sering dengan bantuan alat yang sangat canggih, sehingga benda-benda yang sangat kecil proton dan electron maupun yang sangat jauh benda ruang angkasa dapat diopservasi dengan jelas. 
Esterberg dalam Sugiyono (2013: 316-329). Menyatakan bahwa wawancara adalah salah satu metode untuk dapat mendapatkan data anak atau orangtua dengan mengadakan hubungan secara langsung dengan informan atau pertemuan dua orang untuk bertukar informasi dan ide melalui Tanya jawab, sehingga dapat dikontruksikan makna dalam suatu topic tertentu.

Dokumen merupakan catatan peristiwa yang sudah berlalu. Dokumentasi bisa berupa tulisan, gambar, atau karya monumental dari seseorang. Dokumentasi berbentuk tulisan misalnya catatan harian, sejarah kehidupan (life histories), cerita biografi, peraturan kebijakan, Dokumen yang berbentuk gambar misalnya foto, gambar hidup, sketsa dan lain-lain. Dokumen yang berbentuk karya misalnya karya seni, yang dapat berupa gambar, patung film, dan lain-lainya.

Dalam teknik pengumpulan data, triangulasi diartikan sebagai teknik pengumpulan data yang bersifat menggabungkan dari berbagai teknik pengumpulan data dan sumber data yang telah ada (Sugiyono, 2013:327). Bila peneliti melakukan pengumpulan data dengan triangulasi, maka sebenarnya peneliti mengecek kredibilitas data, yaitu mengecek kredibilitas data dengan berbagai teknik pengumpulan data dan sebagai sumber data, Triangulasi tekni, berarti penelitian menggunakan teknik penggumpulan data yang berbeda-beda untuk mendapatkan data sumber yang sama.

\section{HASIL DAN PEMBAHASAN}

Dalam melakukan pengolahan data, peneliti menggunakan pedoman wawancara terencana terstruktur yang akan diberikan oleh beberapa responden yang dijadikan sebagai sumber data. Selanjutnya peneliti terlebih dahulu menyiapkan beberapa pertayaan pedoman wawancara yang akan dijawab oleh para responden untuk mendapatkan hasil jawaban terkait dengan informasi yang dibutuhkan oleh peneliti. Selain itu pada saat kegiatan wawancara berlangsung, peneliti kemudian mengumpulkan jawaban pada responden sebanyak-banyaknya mengenai topik penelitian yang sedang di teliti. Ketika jawaban para responden telah berhasil terkumpul dengan baik, peneliti kemudian melakukan analisa data dengan menarik kesimpulan dari semua jawaban yang telah tersedia.

Sedangkan pada kegiatan observasi yang telah dilaksanakan, peneliti kemudian melakukan data dengan mempersiapakan format observasi yang berisi variable maupun 
sub variable terkait dengan objek yang di observasi. Pada saat kegiatan observasi dilaksanakan, peneliti kemudian memberikan tanda cek $(\sqrt{ })$ pada bagian kolom yang telah dilaksanakan. Pemberian tanda cek $(\sqrt{ })$ dilakukan ketika objek yang sedang di observasi telah memilki standar, serta syarat yang ditentukan dalam menunjang serta mendukung pelaksanaan pendidikan. Dengan adanya pemberian cek $(\sqrt{ })$ yang dilakukan oleh peneliti, maka peneliti dapat memperoleh data, serta informasi yang dibutuhkan sebagai penguat penelitian yang sedang diteliti. Data yang berhasil terkumpul dengan baik sebagai hasil kegiatan observasi yang dilakukan di SMK 28 Oktober Jakarta oleh peneliti. Kemudian di olah dengan menarik, kesimpulan berdasarkan pemberian cek $(\sqrt{ })$ yang telah diberikan ke dalam format observasi yang telah dipersiapkan oleh peneliti. Dengan melakukan pengolahan data dengan baik, maka peneliti mendapatkan hasil yang berdasarkan topik penelitian yang diteliti oleh peneliti.

Pelayanan bimbingan dan konseling yang dilakukan oleh guru bimbingan dan konseling dalam mengefektipkan layanan bimbingan dan konseling untuk meningkatkan kepercayaan diri pada siswa menggambarkan bahwa guru bimbingan dan konseling cukup baik dalam meningkatkan pelayanan bimbingan dan konseling di sekolah. Hal ini terlihat dari kumpulan hasil wawancara yang dilakukan terhadap beberapa pihak yang dijadikan sebagai sumber data yang terkait masih terdapat hambatan kecil dalam melakukan kondisi siswa di sekolah yang kurang percaya diri.

Tidak hanya itu, standar pelayanan bimbingan dan konseling berserta pendukung yang terdapat di dalamnya, terkait dengan beberapa kumpulan dokumen yang dimiliki oleh guru bimbingan dan konseling, serta catatan kasus yang tersusun secara rapi oleh guru bimbingan dan konseling dengan adanya tindak lanjut yang dilakukan oleh guru bimbingan dan konseling dalam menanggani, serta membantu siswa untuk menyelesaikan permasalahan yang terjadi pada siswa. Selain itu, adanya dukungan fasilitas mencakup ketersediaan sarana dan prasarana penunjang lainya juga membantu siswa dalam mengikuti kegiatan yang bersifat positif serta membentuk perilaku siswa yang baik sehingga pelaksanaan layanan bimbingan dan konseling berjalan secara baik oleh guru bimbingan dan konseling dalam meningkatkan percaya diri pada siswa di SMK 28 Oktober Jakarta.

Pada hasil wawancara yang telah dilaksanakan oleh peneliti terhadap beberapa responden dari siswa kelas XA yang dijadikan sebagai sumber data menyatakan bahwa 
peran guru bimbingan dan konseling sangat dibutuhkan dan membantu siswa yang bermasalah, siswa sangat terbantu dengan layanan bimbingan dan konseling yang diberikan oleh guru bimbingan dan konseling siswa lebih nyaman untuk mengungkapkan permasalahan yang ada, lebih terbuka lagi siswa lebih dekat lagi, disamping kesiapan guru bimbingan dan koseling untuk memberikan layanan dan bantuan pada siswa.

Pada hasil wawancara yang diperoleh oleh peneliti, para responden juga menilai bahwa guru bimbingan dan koseling aktif dalam menjalankan layanan bimbingan dan konseling di sekolah terutama dalam membantu siswa yang mengalami rasa kurang percaya diri dengan melakukan pemberian layanan bimbingan individu dan bimbingan kelompok berupa pemberian materi tentang percaya diri siswa yang terjadi di sekolah. Serta melakukan pembinaan terhadap prilaku siswa di sekolah SMK 28 Oktober Jakarta.

Selain itu, kedisiplinan yang diterapkan oleh pihak sekolah kepada siswa membentuk prilkau siswa lebih baik yang bertujuan agar siswa dapat melakukan hubungan yang baik lebih harmonis tidak ada kesenjangan antar siswa, lebih percaya diri lagi di lingkungan sekolah. Dengan adanya keaktifan guru bimbingan dan konseling untuk menciptakan percaya diri pada siswa, serta melaksanakan layanan bimbingan dan koseling di sekolah maka terciptanya hubungan dan komunikasi antara siswa yang satu dengan yang lain sehingga terjalin dengan baik.

Selanjutnya hasil wawancara yang dilakukan dengan guru bimbingan dan konseling di sekolahan, wali kelas dan siswa kelas X menegaskan bahwa selama ini kerjasama yang dilakukan oleh guru bimbingan dan konseling dengan beberapa pihak sekolah terhadap pelayanan bimbingan dan konseling yang di lakukan oleh guru bimbingan dan konseling berjalan dengan baik dalam menangganni siswa yang kurang percaya diri di sekolah. Hal ini sesuai keterangan guru bimbingan dan konseling yang menyatakan bahwa selama melakukan pantauan terhadap siswa yang berada di lingkungan sekolah hanya beberapa siswa yang mengalami kurang percaya diri tidak semua dan bisa teratasi.

Dengan adanya pemberian layanan individu maupun layanan kelompok serta melakukan penanganan yang tepat pada siswa yang mengalami masalah di sekolah dalam kurang percaya diri di sekolah, menunjukan bahwa guru bimbingan dan konseling selalu berupaya melakukan kerja sama yang baik antara pihak-pihak seperti keluarga, masyarakat, guru bidang studi dalam memberikan binaan, wali kelas, serta pantauan 
terkait dengan tingkah laku siswa di sekolah maupun di luar sekolah, sehingga dapat memperoleh laporan terkait dengan informasi mengenai tingkah laku siswa.

Kegiatan observasiyang dilakukan oleh peneliti menunjukan bahwa sarana dan prasarana yang dimiliki oleh SMK 28 Oktober Jakarta sudah tertata dengan baik. Bahkan berkas beserta dokumen yang dimiliki oleh guru bimbingan dan konseling sudah lengkap sehingga dapat dijadikan panduan dalam melaksanakan layanan bimbingan dan konseling di sekolah. Tidak hanya itu, lingkungan, serta kondisi sekolah yang begitu harmonis dan kondusif, serta menjadi kekuatan tersendiri bagi guru bimbingan dan konseling untuk melakukan kerja sama yang baik dengan para guru yang terdapat di SMK 28 Oktober Jakarta. Dari hasil observasi yang dilakukan, maka peneliti memperoleh gambaran mengenai ruang bimbingan dan konseling yang tertata dengan baik. Selain itu pada ruang bimbingan dan konseling juga tersedia adanya ruang layanan bimbingan dan konseling individu, dimana pada saat siswa mengalami permaslahan di sekolah, guru bimbingan dan konseling mengarahkan siswa menuju rauang layanan bimbingan dan konseling individu untuk dilakukan prosese dan tindak lanjut oleh guru bimbingan dan konseling.

Pada kegiatan observasi yang dilakukan oleh peneliti, diperoleh informasi terkait dengan kondisi sekolah SMK 28 Oktober Jakarta yang dikategorikan "baik” dalam mendukung kegiatan layanan bimbingan dan konseling di sekolah, dimana pada saat kondisi ini terdapat suasana hubungan serta komunikasi antara guru bimbingan dan konseling antara guru bimbingan dan konseling yang tergolong baik, bahkan tergambarnya kekompakan antar guru bimbingan dan konseling dengan guru yang lain dengan baik dalam melakukan kerja sama pada pelaksanaan pendidikan beserta layanan bimbingan dan konseling terutama dalam meningkatkan percaya diri siswa.

Penelusuran dokumen yang dilakukan oleh peneliti di sekolah menunjukan bahwa adanya kelengkapan dokumen yang dimiliki oleh guru bimbingan dan konseling di sekolah. Hal ini menggambarkan bahwa guru bimbingan dan konseling di sekolah SMK 28 Oktober Jakarta mencatat berbagai hal-hal penting terkait dengan pelaksanaan layanan bimbingan dan konseling di sekolah. Pada penelusuran dokumen yang dilakukan oleh peneliti di sekolah, Dapat mencakup adanya progam bimbingan dan konseling lainya yang terdiri dari progam bimbingan harian dan konseling mengenai tugas yang di berikan oleh guru bimbingan konseling di sekolah, progam mingguan bimbingan dan konseling di sekolah berkaitan dengan rutinitas serta kewajiban yang dilaksanakan setiap 
minggunya oleh guru bimbingan dan konseling sekolah, serta adanya progam bulanan bimbingan dan konseling yang menunjukan dengan aktifitas serta kegiatan yang dilakukan setiap bulanya oleh guru bimbingan dan konseling di sekolah.

Pada dokumen terkait dengan progam bimbingan dan konseling di sekolah, juga terdapat gambaran mengenai pembagian jadwal guru bimbingan dan konseling di sekolah beserta daftar nama guru bimbingan dan konseling yang terbagi atas satu orang guru bimbingan dan konseling menjalankan pelaksanaan pelayanan bimbingan dan konseling untuk siswa kelas $\mathrm{X}$, satu orang guru bimbingan dan konseling memberikan pelayanan bimbingan dan konseling untuk kelas $\mathrm{X}$, dan satu orang guru bimbingan dan konseling menjalankan tugasnya dan memberikan pelayanan bimbingan konseling kepada siswa kelas $\mathrm{X}$ dengan masing masing jadwal aktif tiga kali dalam seminggu sesuai dengan jam pelayanan yang diberikan.

Selain itu terdapatnya catatan kasus siswa yang dimiliki oleh guru bimbingan dan konseling memberikan gambaran bahwa selama menjalankan tugas serta kewajiban sekolah, guru bimbingan dan konseling senantiasa mengisi serta mencatat terkait berbagai permasalahan yang di hadapi siswa di sekolah dengan di sertai tanggal kejadian suatu peristiwa yang di alami oleh siswa. Catatan kasus siswa yang dimiliki oleh guru bimbingan dan konseling, memuat tentang adanya tindakan lanjut yang dilakukan oleh guru bimbingan konseling dalam menangani siswa yang bermasalah, daftar nama siswa beserta permasalahan yang di hadapi siswa, serta adanya paraf yang tercantum di dalamnya terdiri dari paraf untuk orang tua, paraf untuk siswa, dan paraf untuk konseling. Paraf yang terdapat di dalam catatan kasus siswa menunjukan adanya keterlibatan serta kerja sama antara orang tua, siswa, serta konseling dengan baik dalam membantu siswa menyelesaikan permasalahan siswa di sekolah. Catatan kasus siswa yang dimiliki oleh guru bimbingan dan konseling mulai dilakukan pengisian dan pencatatan permasalahan siswa dari tahun 2008 sampai pertengahan tahun 2016.

Dokumen lainya seperti adanya atribut dan serta mekanisme, serta prosedur kerja lainya terkait dengan bimbingan dan konseling yang di bingkai dengan pas photo yang tergantung di dinding, memberikan gambaran bahwa pelaksanaan bimbingan dan konseling yang dilakukan berdasarkan standar yang telah ditentukan, serta berdasarkan panduan-panduan layanan bimbingan dan konseling terutama pada pelaksanaan yang mengacu terhadap pola 17 plus. 
Dengan adanya keaktifan pelaksanaan layanan bimbingan dan konseling beserta panduan terkait dengan prosedur guru bimbingan dan konseling di sekolah, menunjukan bahwa adanya peningkatan mutu serta kualitas yang dimiliki oleh guru bimbingan dan konseling dalam menjalankan tugas beserta kewajibanya dengan baik, sehingga guru bimbingan dan konseling dapat mencegah permasalahan yang terjadi pada siswa terutama siswa yang menggalami kurang percaya diri di SMK 28 Oktober Jakarta. Dalam melakukan penagganan kurangnya percaya diri pada siswa yang terjadi disekolah, guru bimbingan dan konseling senantiasa aktif untuk membantu menanggani kurang percaya diri pada siswa disekolah melalui pelaksaan kegiatan layanan bimbingan dan konseling dengan baik, sehingga guru bimbingan dan konseling dapat menciptakan lingkungan kondusif serta kenyamanan bagi seluruh guru bidang studi lainnya beserta siswa yang terlibat di dalam lingkungan sekolah. Hal ini senada dengan pendapat Salahudin (2010:127) yang dikutip oleh Soeparlan Kasyadi dkk. (2014:49), menyatakan bahwa terdapatnya fungsi preventif, yaitu fungsi yang berkaitan dengan upaya konselor untuk senantiasa menggantisipasikan berbagai masalah yang mungkin terjadi dan berupaya untuk mencegahnya supaya tidak dialami oleh konseli.

Melalui adanya fungsi preventif yang dilakukan oleh guru bimbingan dan konseling maka guru bimbingan dan konseling dapat melakukan pengawasan serta memberikan arahan atau bimbingan yang baik terhadap sikap serta prilaku siswa sehingga dapat mencegah terjadinya permasalahan yang ditimbulkan di sekolah.

Selain itu dengan adanya adanya lingkungan yang tercipta secara kondusif dan nyaman bagi seluruh warga sekolah SMK 28 Oktober Jakarta, maka guru bimbingan dan konseling dapat membentuk komunikasi yang baik dengan semua guru serta siswa yang terdapat di sekolah, sehingga guru bimbingan dan konseling dapat menjalin kerja sama anata guru bidang studi, orang tua, beserta siswa di sekolah dengan baik. Mengarah pada pendapat Sarlito (2012:281), menjelaskan bahwa tindakan pencegahan yang paling utama adalah berusaha menjaga keutuhan dan keharmonisan keluarga sebaik-baiknya. Dengan menjaga keutuhan dan keharmonisan keluarga baik di rumah maupun di sekolah, maka pembentukan perilaku anak akan semakin berkembang dengan baik, serta memberikan arahan dalam bersikap serta saling menghargai orang lain, sehingga tidak percaya diri pada siswa di sekolah dapat diminimalisirkan secar berlahan.

Selain itu berdasarkan kesimpulan dari hasil observasi, hasil wawancara, serta 
dokumentasi yang terkait dalam pelaksanaan layanan bimbingan dan konseling memberikan gambaran bahwa guru bimbingan dan konseling melakukan pelaksanaan pelayanan bimbingan dan konseling di sekolah SMK 28 Oktober Jakarta sesuai dengan mekanisme serta prosedur kerja dengan baik, sehingga guru bimbingan dan konseling memiliki pemahaman mengenai pencegahan tindakan untuk menangganni tidak percaya diri pada siswa di sekolah melalui terciptanya kerja sama, serta komunikasi yang baik antara guru bimbingan dan konseling, serta lingkungan sekolah yang tercipta secara kondusif dan nyaman di sekolah SMK 28 Oktober Jakarta.

\section{SIMPULAN}

Kepala sekolah memiliki peran dalam mengkoordinasi serta menerima informasi mengenai siswa, serta mencatat berbagai informasi yang diperoleh dari guru bimbingan dan konseling untuk dikelola dengan baik dan dijadikan sebagai bahan pertimbangan kepala sekolah dalam memberikan kebijakan mengenai kinerja guru untuk lebih ditingkatkan lagi secara lebih baik, terutama dalam mencegah tidak percaya diri pada siswa.

Selain itu dalam mendukung guru bimbingan dan konseling yang berperan aktif dalam menjalankan layanan bimbingan dan koseling, kepala sekolah berupaya melakukan kerja sama yang baik antara guru bimbingan dan konseling dengan guru-guru bidang studi agar berupaya dalam menciptakan lingkungan kondusif dengan memiliki hubungan yang baik antara guru dengan siswa. Kepala sekolah juga memiliki tugas dalam membantu guru bimbingan dan konseling untuk memberikan fasilitas penunjang dalam menyusun prosedur serta langkah-langkah mengenai pemberian layanan kepada siswa, sehingga guru bimbingan dan konseling secara baik dalam dalam rangka membantu mengatasi permasalahan yang terjadi pada siswa.

Guru bimbingan dan konseling membuat progam mengenai mekanisme kerja bimbingan dan konseling secara terarah, yang bertujuan untuk memahami, serta dapat memperbaiki kinerja guru bimbingan dan konseling dalam memberikan layanan bimbingan dan konseling dengan baik di sekolah. Tidak hanya itu, layanan bimbingan dan konseling yang diberikan kepada siswa sangat membantu siswa untuk lebih percaya diri lagi di sekolah, sebagai hasil observasi yang dilakukan oleh peneliti. Selain itu, siswa juga memiliki inisiatif dengan mendatangi ruang bimbingan dan konseling yang bertujuan 
dalam melakukan layanan bimbingan dan konseling sehinga masalah yang terjadi pada siswa dapat teratasi dengan segera. Hal ini juga tidak terlepas dari adanya kerja sama yang dilakukan oleh guru bimbingan dan konseling dengan guru studi, wali kelas, dan temanteman sekolahnya, serta melakukan kerja sama dalam membantu siswa untuk mengatasi permasalahan yang dialaminya untuk mencegah terjadinya permasalahan yang besar sehingga layanan bimbingan dan konseling dapat terlaksana dengan baik di sekolah memlalui hubungan serta komunikasi yang erat antara guru bimbingan dan konseling dengan siswa.

Staff kesiswaan memiliki tugas dalam mencatat serta mengolah data mengenai informasi siswa beserta permasalahan yang dihadapi siswa sehingga data-data tersebut dapat dijadikan sebagai bahan pedoman bagi guru bimbingan dan konseling dalam mengambil suatu keputusan terhadap pencegahan yang di berikan oleh guru bimbingan dan konseling terhadap siswa. Dalam menyelenggarakan sebuah pendidikan secara baik, staff kesiswaan melakukan kerja sama dengan guru bimbingan dan konseling serta mengumpulkan informasi yang sebanyak-banyaknya dari guru bimbingan dan konseling sehingga dapat dijadikan sebagai bahan rujukan yang baik dalam meningkatkan kepercayaan diri pada siswa.

Wali kelas selain memiliki tugas dalam mendidik dan mengajar siswa juga berupaya dalam melakukan kerjasama secara baik dengan guru bimbingan dan konseling dalam mengadakan pelaporan kepada guru bimbingan dan konseling terkait dengan tindakan-tindakan yang dilakukan oleh siswa yang kurang baik selama proses belajar mengajar berlangsung di kelas. Tidak hanya itu, selama wali kelas mengadakan pemangilan terhadap siswa yang bermasalah terkait dengan prilalu siswa yang kurang baik di kelas. Sehingga dapat dijadikan sebagai bahan laporan yang diperoleh guru bimbingan dan konseling dalam memberikan layanan bimbingan dan konseling dengan secara baik, serta dapat dijadikan sebagai laporan untuk mempertimbangkan dalam mengambil keputusan dengan tepat.

Pada saat melakukan proses belajar mengajar di sekolah, siswa tentunya yang tidak percaya diri di sekolah. Maka eferktifitas layanan bimbingan dan konseling sangat berperan dan membantu dalam menangganni siswa yang kurpercaya diri. Selain itu hubungan yang harmonis antara siswa yang satu dengan guru bimbingan dan konseling di sekolah berjalan dengan baik, sehingga siswa memiliki inisiatif sendiri dalam 
mengikuti layanan bimbingan dan konseling di sekolah, sehingga siswa merasa senang dan nyaman saat berada di lingkungan sekolah sehingga siswa dapat bergaul dengan baik, proses belajar akan lebih efektif.

Selain itu pada kegiatan observasi yang dilakukan oleh peneliti terhadap kondisi ruangan bimbingan dan konseling menunjukan bahwa tata ruang yang tidak begitu besar, serta kurangnya perlengkapan seperti perpustakaan untuk guru bimbingan dan konseling yang belum tersedia dengan baik. Hal ini menunjukan bahwa ukuran ruangan bimbingan dan konseling kurang begitu luas sehingga tidak memungkinkan untuk menyediakan perpustakaan bagi guru bimbingan dan konseling.

Pada observasi yang dilakukan peneliti, banyak fasilitas berupa sarana dan prasarana yang mendukung terhadap pelaksanaan pendidikan di sekolah. Sarana dan prasarana yang di sediakan pihak sekolah dapat dikatakan baik di karenakan pemanfaatan fasilitas yang dilakukan dengan baik sehingga siswa dapat menyalurkan bakat beserta minat dan bakat yang dimiliki sehingga siswa dapat terarah pada kegiatan yang positif, serta dapat membuat siswa banyak beraktifitas di sekolah. Berdasarkan kesimpulan di atas, maka peneliti dapat menarik kesimpulan bahwa layanan bimbingan dan konseling dalam meningkatkan kepercayaan diri di sekolah SMK 28 Oktober Jakarta, cukup efektif.

\section{DAFTAR PUSTAKA}

Charlotte Buhler. 1980. Masapuber http://lib.unnes.ac.id/1017/1/1955.pdf. Diakses tanggal 20 Juli 2016. Jam 10.00. WIB.

Haryanto. 2010. Pengertian Kepercayaan Diri.http://belajarpsikologi.com/pengertiankepercayaan-diri/.html. Diakses tanggal 17 Juli 2016. Jam 09.00 WIB.

Ilawati.2014. Menghilangkan Atau Menggatasi Tidak Percaya Diri.http://www.ilawatiapt.com/cara-menghilangkan-rasa-minder-dan-kurang-percaya-diri/.html. Diakses tanggal 16 Juli 2016. Jam 10.00 WIB.

James Neill. Buku Pintar. 2014. Tampil Percaya Diri. Yogyakarta: Araska.

Kasyadi, S., dkk. (2014). Strategi Belajar dan Pembelajaran. Tangerang: PT Pustaka Mandiri.

Mastuti. 2008. Kepercayaan diri. https://eprints.uns.ac.id/20980/3/BAB_II.pdf. Diaksestanggal 17 Juli 2016 Jam 09.00 WIB. 
Prayitno, dan Erman Amti.2004. Dasar-Dasar Bimbingan Dan Konseling. Jakarta: RinekaCipta.

Prayitno. 2012. Jenis Layanan Dan Kegiatan Pendukung Konseling. Jakarta: RinekaCipta.

Sarlito Wirawan Sarwono. 2012. Psikologi Remaja. Jakarta: PT. Raja Grafindo Persada.

Sugiyono. 2013. Metode Penelitian Kombinasi. Bandung: Alfabeta.

Salahudin. 2010. Fungsi preventif.http://www.slideshare.net/uus_yuli/ppt-uas-admin238416143. Diakses tanggal 16 Juli 2016. Jam 10.00 WIB.

Thantaway. 2005. Percaya diri.http://belajarpsikologi.com/pengertian-kepercayaan-diri/.

Undang-undang No. 20 Tahun 2003 tentang Sistem Pendidikan Nasional.

Wiranegara. 2010. Percayaan Diri.http://belajarpsikologi.com/pengertianPepercayaan-diri/.html.Diakses tanggal 16 Juli 2016 Jam 10.00 WIB. 